\title{
PENGARUH GREEN MARKETING, KESADARAN LINGKUNGAN DAN KESEHATAN TERHADAP KEPUTUSAN PEMBELIAN PRODUK PANGAN ORGANIK MELALUI SIKAP
}

\author{
THE EFFECT OF GREEN MARKETING, ENVIRONMENTAL AND HEALTH AWARENESS ON PURCHASING \\ DECISIONS OF ORGANIC FOOD PRODUCTS THROUGH ATTITUDES
}

\author{
Caselia Ajeng Puspitasari ${ }^{* 1}$, Lilik Noor Yuliati ${ }^{* *}$, Farit Afendi ${ }^{* * *}$ \\ *) Sekolah Bisnis, IPB University \\ Jl. Raya Pajajaran, Bogor 16151, Indonesia \\ ${ }^{* *}$ Departemen Ilmu Keluarga dan Konsumen, Fakultas Ekologi Manusia, IPB University \\ Gedung GMSK Lantai 2, IPB Dramaga, Bogor 16680, Indonesia \\ ${ }^{* * *}$ Departemen Statistika, Fakultas Matematika dan Ilmu Pengetahuan Alam, IPB University \\ Jl. Meranti Wing 22 Level 4, IPB Dramaga, Bogor 16680, Indonesia
}

\begin{abstract}
This study did to analyze the effect of green marketing, environtmental awareness and health on purchasing decisions of organic food products through attitudes. The purpose of this study were (1) To analyze effect of green marketing, environmental awareness, and health awareness on attitudes. (2) To analyze effect of green marketing, environmental awareness, health awareness, and attitudes on purchasing decisions of organic food products. (3) To formulate managerial implications for enhanced the purchase of organic products. The data in this study was analyzed by using Structural Equation Modeling (SEM) with total of sample was 220 respondents. The results of this study were showed that green marketing and environmental awareness had an effect on attitudes. Green marketing and health awareness had an effect on purchasing decisions of organic food products. Managerial implications that could be given were to proved that the product was safe to consumed by ensured this product had been certified, company always improved their promotion with using social media or by any event, and company guaranteed the product they produced was eco-friendly.
\end{abstract}

Keywords: attitudes, environmental awareness, green marketing, health awareness, purchasing decisions

\begin{abstract}
Abstrak: Penelitian dilakukan untuk menganalisis pengaruh green marketing, kesadaran lingkungan dan kesehatan terhadap keputusan pembelian produk pangan organik melalui sikap konsumen produk Bionic Farm. Adapun tujuan dari penelitian ini adalah (1) Menganalisis pengaruh green marketing, kesadaran lingkungan, dan kesadaran kesehatan terhadap sikap. (2) Menganalisis pengaruh green marketing, kesadaran lingkungan, kesadaran kesehatan, dan sikap terhadap keputusan pembelian produk pangan organik. (3) Merumuskan implikasi manajerial untuk meningkatkan pembelian produk organik. Data dalam penelitian ini dianalisis menggunakan Structural Equation Modeling (SEM) dengan jumlah sampel sebanyak 220 responden dengan teknik pengambilan sampel menggunakan purposive sampling. Hasil penelitian menunjukkan bahwa green marketing dan kesadaran lingkungan berpengaruh terhadap sikap. Green marketing dan kesadaran kesehatan berpengaruh terhadap keputusan pembelian. Implikasi manajerial yang dapat diberikan, yaitu membuktikan bahwa produk yang dihasilkan aman dikonsumsi dengan menjamin produk ini tersertifikasi, meningkatkan promosi dengan memanfaatkan sosial media atau melalui event-event, dan perusahaan menjamin produk yang diproduksi ramah lingkungan.
\end{abstract}

Kata kunci: sikap, kesadaran lingkungan, green marketing, kesadaran kesehatan, keputusan pembelian

\footnotetext{
${ }^{1}$ Alamat korespondensi:

Email: caselia_ajeng@ymail.com
} 


\section{PENDAHULUAN}

Kesadaran masyarakat akan pentingnya kualitas hidup dan kesehatan yang baik akan membuka peluang besar bagi bisnis produk pangan organik. Hal ini tergambar dari hasil observasi dari Savale et al. (2012) menjelaskan bahwa konsumen berkontribusi terhadap degradasi lingkungan dengan membeli produk yang berbahaya atau menggunakan dengan cara tidak aman bagi lingkungan. Masyarakat menyadari bahaya yang ditimbulkan dari penggunaan bahan kimia sintetis dalam pertanian. Hal ini membuat masyarakat akan semakin selektif dalam memilih bahan pangan yang aman bagi kesehatan dan ramah lingkungan. Pangan organik memiliki beberapa keistimewaan yaitu kandungan gizi yang lebih tinggi, lebih sehat, dan ramah lingkungan jika dibandingkan dengan makanan yang diproduksi secara konvensional atau non organik. Sejumlah bukti menunjukkan bahwa pangan organik dapat membantu mengurangi risiko kesehatan karena memiliki sedikit paparan sisa pestisida dan logam berat pada buah-buahan, sayur-sayuran, biji-bijian dibandingkan diproduksi secara konvensional. Ada beberapa syarat tertentu yang menentukan suatu produk pangan dikatakan organik, yaitu (1) tidak mengandung pupuk sintesis dan tidak terpapar pestisida kimia (sayur-sayuran, buah-buahan, biji-bijian); (2) pangan tersebut bukan hasil rekayasa genetika (GMO); (3) tidak diberikan hormon pertumbuhan; (4) tanpa radiasi; dan (5) tanpa anti biotik untuk daging, unggas, telur, dan produk susu (International Federation of Organic Agriculture Movements, 2018).

Berbagai macam tantangan yang dihadapi para produsen produk organik dalam rangka memasarkan produk dengan mengedepankan konsep organik. Salah satu bentuk tuntutan konsumen yaitu menginginkan kesehatan akibat meningkatnya penyebaran penyakit yang disebabkan makanan maka produsen makanan memunculkan produk dengan jenis makanan organik sebagai makanan yang sehat, tanpa bahan kimia tambahan dan aman untuk dikonsumsi. Istilah "back to nature dan go green" menjadi misi yang digiatkan di dunia dan menjadi budaya yang kembali dimunculkan di masyarakat. Jenis makanan organik menjadi salah satu isu yang kembali dipublikasikan karena berhubungan dengan kesehatan manusia dan kepedulian lingkungan.
Munculnya kesadaran akan permasalahan lingkungan dan kesehatan memicu dunia industri untuk menghadirkan konsep pemasaran yang mengedepankan isu lingkungan dan kesehatan atau yang lebih dikenal dengan konsep green marketing. Pendekatan pemasaran yang berbasis pada pelestarian lingkungan merupakan terobosan baru dalam bidang pemasaran yang diharapkan akan mendapatkan peluang pasar besar yang mampu menciptakan kepuasan bagi konsumen dan keuntungan bagi pelaku bisnis. Green marketing sebagai konsep strategi pemasaran produk oleh produsen bagi kebutuhan konsumen yang peduli lingkungan hidup (Yazdanifard dan Mercy, 2011). Seiring dengan kesadaran masyarakat terhadap isu kesehatan dan lingkungan maka strategi bisnis dengan konsep green marketing menjadi peluang bisnis yang menjanjikan. Adanya konsep tersebut akan lebih meyakinkan masyarakat dalam memutuskan untuk membeli produk pangan organik tersebut. Pernyataan tersebut sesuai dengan hasil penelitian yang dilakukan Balawera (2013) yang melakukan penelitian perihal pengaruh green marketing terhadap keputusan pembelian produk organik yang mana diperoleh hasil bahwa green marketing berpengaruh terhadap keputusan pembelian produk organik. Selain itu adanya kesadaran masyarakat atas isu kesehatan dan lingkungan juga menjadi salah satu hal yang memengaruhi keputusan pembelian konsumen. Ini sesuai dengan hasil penelitian yang dilakukan oleh Shaharudin et al. (2010) menunjukkan bahwa kesadaran kesehatan berpengaruh terhadap keputusan pembelian produk organik ataupun nonorganik dan penelitian yang dilakukan oleh Syahrivar dan Rizky (2017) yang menunjukkan bahwa kesadaran lingkungan berpengaruh terhadap keputusan membeli produk ramah lingkungan.

Selain konsep green marketing dan isu kesadaran terhadap kesehatan dan lingkungan, sikap juga menjadi satu hal yang berpengaruh terhadap keputusan pembelian. Sikap ini menjelaskan ekspresi dari perasaan terhadap yang disukai dan tidak disukai terhadap suatu produk (Schiffman dan Kanuk, 2010). Jika konsumen suka terhadap produk tersebut maka mereka akan memutuskan untuk membeli produk tersebut dan begitupun sebaliknya. Pernyataan ini sesuai dengan hasil penelitian yang dilakukan oleh Naido dan Ramatsetse (2016) yang menunjukkan bahwa sikap berpengaruh keputusan pembelian. 
PT Bionic Farm sebagai unit bisnis yang bergerak dalam bidang produksi dan pemasaran pangan organik hadir dalam upaya untuk membantu masyarakat agar lebih mudah mendapatkan pangan organik sesuai harapannya secara bersaing. Semakin besarnya minat konsumen untuk mengkonsumsi produk pangan organik menjadi suatu peluang besar bagi PT Bionic Farm untuk mengembangkan usahanya. Adapun upaya untuk berjalannya bisnis secara berkelanjutan maka PT Bionic Farm harus selalu mengembangkan pasar dengan menjaring konsumen-konsumen baru serta memertahankan pasar yang sudah ada. Salah satu cara yang dapat digunakan perusahaan untuk mengembangkan pasarnya yaitu dengan meningkatkan promosi produk dan memperluas kerjasama dengan perusahaan penyalur produk. Bagi PT Bionic Farm ini perihal promosinya masih tergolong kurang dan bahkan perusahaan ini belum memiliki toko resmi yang menyediakan produk secara langsung. Perusahaan ini masih mengandalkan kerjasama ke supermarketsupermarket dan juga menggunakan mode penjualan secara online di sekitar wilayah usaha saja belum menjangkau seluruh Indonesia. Selain itu, semakin banyaknya pesaing yang bergerak di bidang serupa mengharuskan perusahaan harus mampu menangkap peluang dengan mengetahui faktor-faktor yang memengaruhi keputusan pembelian yang dilakukan konsumen. Dengan diketahuinya faktor-faktor yang memengaruhi keputusan pembelian maka perusahaan akan melakukan strategi-strategi bisnis sesuai harapan konsumen.

Tujuan dari penelitian ini ialah (1) menganalisis pengaruh green marketing, kesadaran lingkungan, dan kesadaran kesehatan terhadap sikap; (2) menganalisis pengaruh green marketing, kesadaran lingkungan, kesadaran kesehatan, dan sikap terhadap keputusan pembelian produk pangan organik. Penelitian berbatas pada hal yang difokuskan untuk menganalisis pengaruh green marketing, kesadaran lingkungan dan kesehatan terhadap keputusan pembelian produk pangan organik melalui sikap konsumen produk Bionic Farm. Penelitian ini lebih menekankan pada sudut pandang konsumen. Penelitian ini juga memiliki keterbatasan pada alat ukur sikap yang belum dapat mengukur latennya (walaupun nilai validitas dan relabilitas sudah baik).

\section{METODE PENELITIAN}

Penelitian dilakukan di Indonesia tepatnya pada konsumen produk Bionic Farm. Karena sebagian besar penjualan produk Bionic Farm dilakukan melalui media online dan untuk menggambarkan konsumen di Indonesia secara keseluruhan karena tempat penjualan masih terbatas di daerah Jabodetabek maka berdasarkan hal tersebut memungkinkan peneliti melakukan penelitian menggunakan media online dalam bentuk pengisian kuesioner secara online. Waktu pengambilan data dilaksanakan pada bulan April - Agustus 2018. Data yang digunakan dalam penelitian ini adalah data primer dan data sekunder.

Desain dari penelitian ini menggunakan metode cross sectional design dengan teknik pengambilan sampel menggunakan purposive sampling. Kriteria responden dalam penelitian ini adalah konsumen produk Bionic Farm yang sudah pernah membeli dan mengonsumsi produk Bionic Farm dalam kurun waktu 3 bulan terakhir. Pengambilan ukuran sampel dilakukan dengan menggunakan rule of thumb dari structural equation model (SEM). Menurut Hair et al. (2006) jumlah sampel yang dibutuhkan untuk setiap estimated parameter variabel eksogen dan endogen adalah lima hingga sepuluh observasi. Jumlah variabel indikator yang menyusun model SEM pada penelitian berjumlah 36 variabel indikator maka batasan jumlah respondennya adalah $(36 \times 5=180)$ responden sampai dengan $(36 \times 10=360)$ responden. Dan penelitian menggunakan kuesioner online maka jumlah sampel yang diambil adalah 220 responden.

Sikap (Y1) adalah suatu ekspresi yang merefleksikan kepercayan dan kesenangan terhadap suatu objek. Adapun indikator yang menggambarkan sikap dalam penelitian ini ialah (Y1.1) saya percaya bahwa mengonsumsi produk Bionic Farm dapat menjaga kesehatan saya; (Y1.2) saya percaya bahwa dengan mengonsumsi produk Bionic Farm dapat mendukung kegiatan ramah lingkungan; (Y1.3) saya percaya bahwa dengan mengonsumsi produk Bionic Farm dapat meningkatkan kepercayaan diri saya; (Y1.4) saya percaya bahwa produk Bionic Farm sudah teruji organik dari lembaga tersertifikasi; (Y1.5) saya senang mengonsumsi produk Bionic Farm karena memiliki banyak manfaat; (Y1.6) saya senang mengonsumsi produk Bionic Farm karena rasanya yang enak; (Y1.7) saya senang mengonsumsi produk Bionic Farm karena 
kemasannnya yang menarik; dan (Y1.8) saya senang mengonsumsi produk Bionic Farm karena produknya mudah didapatkan (Supriati, 2010).

Keputusan pembelian (Y2) yaitu suatu tindakan dari konsumen untuk membeli kembali dan merekomendasikan suatu produk (Kotler dan Keller, 2009). Proses pengamblan keputusan konsumen dalam pembelian suatu produk terbentuk dari beberapa tahapan yaitu pengenalan dan kesadaran, mencari informasi, evaluasi alternatif, pembelian, konsums, evaluasi pascapembelian dan divestasi (Rahmalia et al. 2016). Adapun indikator yang menggambarkan keputusan pembelian dalam penelitian ini ialah (Y2.1) saya akan membeli kembali produk Bionic Farm dalam waktu 3 bulan mendatang; (Y2.2) saya akan merekomendasikan produk Bionic Farm kepada teman-teman saya; dan (Y2.3) saya akan tetap membeli produk pangan organik Bionic Farm kembali dibandingkan merek lainnya (Kotler, 2002).

Green marketing (X1) adalah suatu proses pemasaran produk-produk yang memfokuskan pada keamanan terhadap lingkungan. Adapun indikator yang menggambarkan green marketing dalam penelitian ini meliputi (1) green product (X1.1, X1.2, X1.3, X1.4, $\mathrm{X} 1.5, \mathrm{X} 1.6, \& \mathrm{X} 1.7)$; (2) green price (X1.8, X1.9, \& $\mathrm{X} 1.10)$; (3) green place (X1.11, X1.12, \& X1.13); dan (4) green promotion $(\mathrm{X} 1.14, \mathrm{X} 1.15, \mathrm{X} 1.16, \& \mathrm{X} 1.17)$ (AMA, 2009).

Kesadaran lingkungan (X2) adalah usaha untuk menumbuhkan dan membina kesadaran untuk melestarikan lingkungan. Adapun indikator yang menggambarkan kesadaran lingkungan dalam penelitian ini ialah (X2.1) saya khawatir mengenai memburuknya kualitas lingkungan di Indonesia; (X2.2) saya menjadikan lingkungan di Indonesia sebagai perhatian utama saya; (X2.3) saya terlibat secara emosional dalam isu-isu perlindungan lingkungan di Indonesia; dan (X2.4) saya sering berpikir tentang cara meningkatkan kualitas lingkungan di Indonesia (Neoloka, 2008).

Kesadaran kesehatan (X3) adalah suatu kepedulian dan perhatian terhadap kesehatan untuk menjadi lebih baik. Adapun indikator yang menggambarkan kesadaran kesehatan dalam penelitian ini ialah (X3.1) saya peduli terhadap kesehatan diri saya; (X3.2) saya menyadari bahwa asupan makanan memengaruhi kesehatan; (X3.3) saya menyadari bahwa pangan organik memiliki manfaat untuk kesehatan; dan (X3.4) saya berusaha untuk mengonsumsi makanan yang sehat (Chen, 2009).

Model dalam penelitian berdasarkan konsep green marketing (AMA, 2009) yang menjelaskan green marketing berdasarkan 4P (product, price, place, dan promotion). Variabel lingkungan berdasarkan konsep Neoloka (2008), kesadaran kesehatan Chen (2009), sikap berdasarkan Suprapti (2010), dan keputusan pembelian produk pangan organik berdasarkan teori Kotler (2002). Berikut kerangka pemikiran dapat dilihat pada Gambar 1.

Data penelitian ini dianalisis menggunakan analisis structural equation modeling (SEM) dengan aplikasi Lisrel 8.5. SEM merupakan teknik analisis gabungan dari dua metodologi disiplin ilmu yaitu perspektif ekonometrika yang memfokuskan pada prediksi dan psychometrika yang mampu untuk menggambarkan konsep model dengan variabel laten atau variabel yang tidak dapat diukur secara langsung akan tetapi diukur melalui indikator-indikatornya (Ghozali dan Latan, 2014).

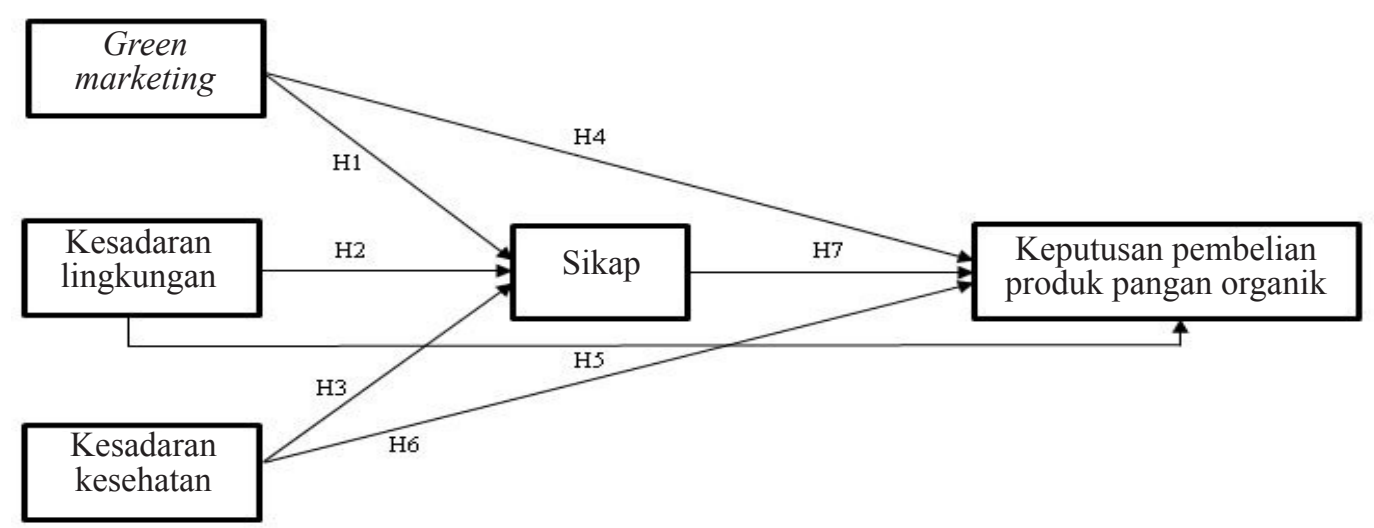

Gambar 1. Kerangka pemikiran penelitian 
SEM mempunyai dua jenis variabel laten yaitu eksogen dan endogen (Wijayanto, 2008). Variabel eksogen selalu muncul sebagai variabel bebas pada semua persamaan yang ada dalam model. Dalam penelitian variabel eksogennya adalah green marketing, kepedulian lingkungan dan kesehatan. Sementara itu, variabel endogen merupakan variabel terikat pada paling sedikit satu persamaan dalam model, meskipun disemua persamaan sisanya variabel tersebut adalah variabel bebas. Dalam penelitian, variabel endogennya adalah sikap dan keputusan pembelian. Menurut Wijayanto (2008), terdapat beberapa tahapan yang harus dilakukan dalam membentuk model SEM, yakni pengembangan model berbasis konsep dan teori, pengembangan diagaram alur (path diagram), konversi diagram alur ke dalam persaman struktural, memilih matriks input dan estimasi model, menilai masalah identifikasi, evaluasi model, serta interpretasi dan modifikasi model. Pada tahapan pengembangan model berbasis konsep dan teori, dilakukan spesifikasi dari variabel-variabel yang akan diteliti dan hubungan antara variabel-variabel tersebut. Adapun hipotesis dari penelitian ini adalah sebagai berikut:

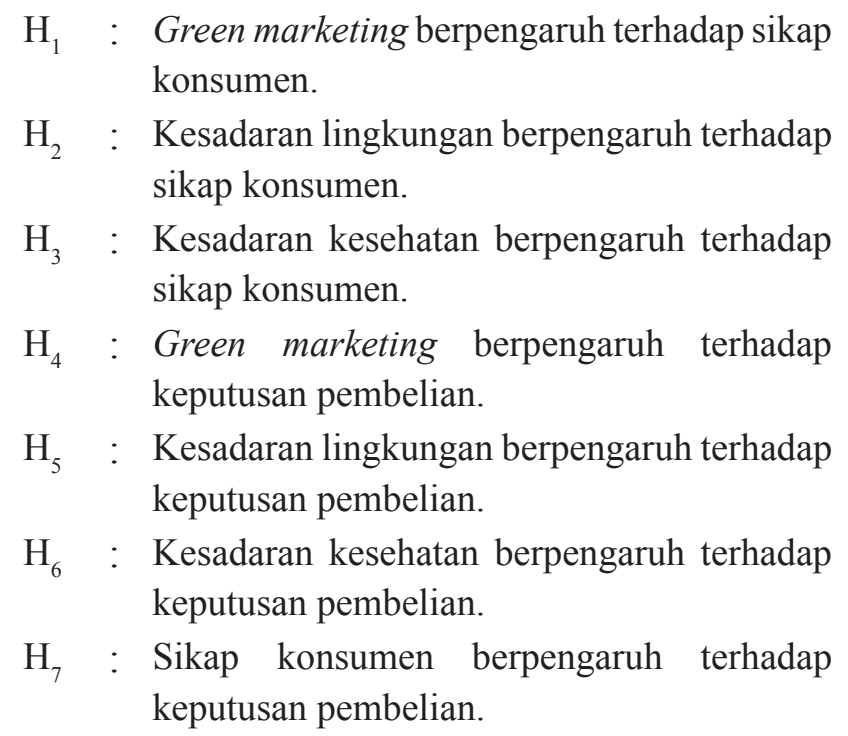

\section{HASIL}

\section{Karakteristik Konsumen dan Perilaku Pembelian Produk Pangan Organik}

Karakteristik dari konsumen produk pangan organik di Bionic Farm ini didominasi oleh usia 25-35 tahun sebanyak 86 orang $(30,09 \%)$. Jenis kelamin yang mendominasi ialah perempuan sebanyak 131 orang (59,55\%). Status pernikahan sudah menikah sebanyak 174 orang $(79,09 \%)$. Pendidikan terakhirnya yaitu sarjana sebanyak 151 orang $(68,64 \%)$. Pekerjaan dari konsumen yaitu ibu rumah tangga sebanyak 59 orang (26,82\%) dengan pendapatan diantara Rp3jt - Rp6jt sebnayak 85 orang $(38,64 \%)$.

Adapun perilaku pembelian konsumen produk pangan organik Bionic Farm dapat diketahui bahwa jenis produk yang biasa dibeli konsumen ialah produk olahan kemasan sebanyak 88 orang (40\%), berat pangan organik yang dibeli sebesar 1-3 kg sebanyak 130 orang $(59,09 \%)$. Adapun biaya yang dikeluarkan untuk membeli produk pangan organik selama sebulan ialah Rp100.000 - Rp 250.000 sebanyak 97 orang (44,09\%). Atribut yang paling dipentingkan konsumen dalam pembelian pangan organik ialah perihal kesadaran kesehatan sebanyak 152 orang $(69,09 \%)$.

\section{Faktor-faktor yang Memengaruhi Sikap dan Keputusan Pembelian}

Analisis yang dilakukan untuk mengetahui faktor-faktor yang memengaruhi sikap dan keputusan pembelian dari Bionic Farm dengan menggunakan analisis SEM. Adapun diperoleh hasil path diagram yang merupakan hasil pengujian hipotesis yang dapat dirangkum pada Tabel 1.

\section{Pengaruh Green Marketing, Kesadaran Lingkungan dan kesadaran Kesehatan terhadap Sikap}

Tabel 1 menunjukkan bahwa green marketing, kesadaran lingkungan berpengaruh signifikan dan memiliki arah positif terhadap sikap sedangkan kesadaran kesehatan tidak berpengaruh siginifikan terhadap sikap. Hal ini berarti jika perusahaan meningkatkan green marketing maka akan semakin meningkatkan sikap konsumen terhadap PT Bionic Farm. Adapun indikator yang paling menggambarkan perihal green marketing ialah indikator promosi dan indikator produk. Green marketing berdasarkan indikator promosi dan produk dapat meningkatkan sikap pembelian produk organik sesuai dengan penelitian-penelitian sebelumnya. Hal yang perlu dilakukan untuk meningkatkan sikap pembelian produk Bionic Farm yaitu promosi melalui pesan lingkungan yang mudah dipahami menyatakan produk Bionic Farm aman untuk dikonsumsi dan terbukti alami. Hal ini didukung oleh logo organik dan produk berkualitas serta memiliki daya saing. Sikap konsumen berdasarkan percaya bahwa produk Bionic Farm mendukung kegiatan ramah lingkungan dan manfaat. Berdasarkan hal tersebut, peningkatan sikap konsumen produk Bionic Farm dapat dilakukan 
melaui green marketing melalui produk dan promosi. Hasil ini sesuai dengan hasil penelitian yang dilakukan Soerjanatamihardja dan Fachira (2017) yang menemukan bahwa green marketing berpengaruh terhadap sikap dan ia juga menambahkan bahwa hal yang paling penting dalam green marketing yaitu produk dan promosi dalam meningkatkan sikap konsumen di Indonesia untuk membeli produk yang bersifat "green".

Kesadaran lingkungan juga menjadi salah satu faktor yang berpengaruh terhadap sikap konsumen dari PT Bionic Farm ini. Hal ini berarti jika perusahaan semakin sadar akan kondisi lingkungan maka akan semakin meningkatkan sikap konsumen terhadap PT Bionic Farm ini.Adapun indikator yang paling menggambarkan penilaian kesadaran lingkungan dari konsumen ialah adanya kekuatiran mengenai buruknya kualitas lingkungan di Indonesia. Hasil penelitian ini sesuai dengan penelitian yang dilakukan oleh Paramitha dan Yasa (2010) yang menemukan kesadaran lingkungan berpengaruh terhadap sikap konsumen dan peneliti juga menambahkan bahwa produk yang memerhatikan lingkungan dan memiliki tanggung jawab sosial adalah penting karena kesadaran dan sikap konsumen terhadap produk ramah lingkungan semakin tinggi.
Hasil berbeda diperoleh pada variabel kesadaran kesehatan yang tidak berpengaruh signifikan terhadap sikap konsumen PT Bionic Farm. Hasil kesadaran kesehatan terhadap sikap pembelian produk organik berbeda dengan hasil penelitian yang telah dilakukan oleh Hansen et al. (2018). Hansen et al. (2018) menjelaskan bahwa konsumen cenderung merasa sehat dengan mengonsumsi produk organik berdasarkan penilaian personalnya. Hasil ini mungkin berbeda yaitu kesadaran kesehatan tidak signifikansi terhadap sikap pembelian produk organik. Selain klaim kesehatan, produk organik Bionic Farm mengkampanyekan kesehatan dan lingkungan. Kesehatan memang merupakan salah satu nilai dari mengonsumsi Bionic Farm namun adanya nilai kepedulian lingkungan yang perlu ditingkatkan untuk meningkatkan sikap konsumen dalam konsumsi produk organik. Merujuk dari hasil penelitian ini menunjukkan bahwa kesadaran akan lingkungan lebih menjadi hal yang memengaruhi sikap konsumen PT Bionic Farm dibandingkan kesadaran kesehatan. Hal ini disebabkan konsumen sudah mengetahui bahwa produk organik untuk meningkatkan kesehatan sedangkan permasalahan lingkungan konsumen belum banyak mengetahui bahwa konsumsi pangan organik dapat meningkatkan kesadaran lingkungan. Hal ini sesuai dengan atribut yang dipentingkan dalam pembelian produk organik dalam perilaku pembelian bahwa kosumen Bionic Farm tidak ada yang peduli terhadap lingkungan.

Tabel 1. Hasil uji hipotesis

\begin{tabular}{|c|c|c|c|}
\hline Variabel laten & $\begin{array}{c}\text { Standardize } \\
\text { Loading Factor }\end{array}$ & $|t-h i t|>1,96$ & Kesimpulan \\
\hline Green Marketing $\rightarrow$ Sikap & 0,83 & 12,51 & H1 Diterima \\
\hline Kesadaran Lingkungan $\rightarrow$ Sikap & 0,19 & 4,04 & H2 Diterima \\
\hline Kesadaran Kesehatan $\rightarrow$ Sikap & $-0,044$ & $-1,23$ & H3 Ditolak \\
\hline Green Marketing $\rightarrow$ Keputusan Pembelian & 0,75 & 3,46 & H4 Diterima \\
\hline Kesadaran Lingkungan $\rightarrow$ Keputusan Pembelian & 0,072 & 0,87 & H5 Ditolak \\
\hline Kesadaran Kesehatan $\rightarrow$ Keputusan Pembelian & $-0,17$ & $-2,50$ & H6 Diterima \\
\hline Sikap $\rightarrow$ Keputusan Pembelian & 0,16 & 0,91 & H6 Ditolak \\
\hline Green Marketing $\rightarrow$ Keputusan Pembelian (Melalui Sikap) & 0,14 & - & Tidak berpengaruh \\
\hline Kesadaran Lingkungan $\rightarrow$ Keputusan Pembelian (Melalui Sikap) & 0,03 & - & Tidak berpengaruh \\
\hline Kesadaran Kesehatan $\rightarrow$ Keputusan Pembelian (Melalui Sikap) & $-0,01$ & - & Tidak berpengaruh \\
\hline
\end{tabular}


Pengaruh Green Marketing, Kesadaran Lingkungan, Kesadaran Kesehatan dan Sikap terhadap Keputusan Pembelian Produk Bionic Farm

Berdasarkan Tabel 1 didapatkan bahwa green marketing dankesadarankesehatan berpengaruh signfikan terhadap keputusan pembelian produk pangan organik Bionic Farm, sedangkan kesadaran lingkungan dan sikap tidak berpengaruh signifikan terhadap keputusan pembelian produk pangan organik Bionic Farm. Pengaruh dari green marketing terhadap keputusan pembelian produk pangan organik Bionic Farm memiliki arah positf yang mana hal ini menunjukkan adanya peningkatan green marketing dari produk pangan organik di Bionic Farm maka akan meningkatkan keputusan pembelian produk pangan organik di Bionic Farm. Green marketing memiliki pengaruh keputusan pembelian berdasarkan indikator produk dan promosi. Analisis pengaruh green marketing signifikan terhadap keputusan pembelian sesuai dengan hasil penelitian yang telah dilakukan oleh Risyamuka dan Mandala (2015). Perlunya memertahankan konsumen lama dengan meningkatkan kualitas produk. Hal yang perlu dijadikan strategi yaitu melakukan promosi dengan baik, harga dan lokasi dipertahankan dan menjaga kualitas produk. Perlunya dilakukan strategi tersebut agar dapat meningkatkan keputusan pembelian produk (Risyamuka dan Mandala 2015; Beltran et al. 2015).

Kesadaran kesehatan signifkan terhadap keputusan pembelian produk organik sesuai dengan hasil penelitian yang telah dilakukan oleh Chekima et al. (2017) dan Asif et al. (2018) namun memiliki arah yang berbeda. Chekimaetal.(2017)menjelaskanbahwaperkembangan produk organik di negara berkembang berdasarkan aspek manfaat yang harus dijelaskan oleh penjual produk organik dan strategi yang dibuat oleh pemasar dalam promosi produk organik. Hal yang paling utama yaitu kebiasan konsumen dalam mengonsumsi produk organik. Berdasarkan hal tersebut, peran pemasar untuk menyusun strategi yang efektif untuk pasar yang lebih baik dan mengurangi ketidakpastian persepsi konsumen terhadap produk organik. Asif et al. (2018) menjelaskan bahwa adanya perlunya pemasaran secara agresif untuk produk organik sehingga konsumen memiliki persepsi terhadap kesehatan dan lingkungan sehingga adanya keputusan untuk membeli produk organik. Namun, konsumen memiliki egoistic motive dalam konsumsi produk organik. Egoistic motive yaitu mementingkan kesehatan dibandingkan lingkungan dalam konsumsi produk organik. Berdasarkan penjelasan penelitian sebelumnya, persepsi kesadaran kesehatan dapat berubah terhadap produk organik sehingga diperlukan pendekatan berdasarkan kebiasan konsumen dalam mengonsumsi produk organik. Berdasarkan atribut yang dipentingkan dalam konsumsi produk organik, hal yang diutamakan dalam mengonsumsi produk organik yaitu kesadaran kesehatan dan klaim kesehatan yang dapat mencapai 80 persen. Hasil tersebut menunjukkan bahwa selama konsumen mengonsumsi produk organik, mereka menyakini bahwa produk tersebut dapat menjaga kesehatan mereka dan tidak peduli produk organik dari produsen manapun selama masih adanya klaim kesehatan dalam produk tersebut. Hal ini dapat dilihat dari karakteristik konsumen yang lebih dari 50 persen pernah membeli produk organik selain Bionic Farm. Berdasarkan hal tersebut, klaim kesehatan bukan menjadi hal utama untuk konsumsi produk organik dari Bionic Farm karena klaim kesehatan dan kesadaran kesehatan dapat diperoleh selama mengonsumsi produk organik baik dari Bionic Farm maupun produsen lainnya. Hal ini yang menyebabkan kesadaran kesehatan memiliki arah yang berlawanan terhadap keputusan pembelian karena konsumsi produk organik apapun dapat menjadi acuan konsumen untuk membeli produk organik tanpa harus memertimbangkan produk dari produsen yang berbeda.

Kesadaran lingkungan tidak signifikan terhadap keputusan pembelian berbeda dengan hasil penelitian yang telah dilakukan Wibowo (2011) dan Syahrivar dan Rizky (2017). Hal yang membedakan dari dua penelitian sebelumya yaitu konsumen Bionic Farm membeli produk organik dengan alasan kesehatan bukan berdasarkan kesadaran lingkungan. Hal ini berdasarkan atribut yang dipentingkan dalam pembelian produk organik. Tidak ada konsumen yang memertimbangkan aspek lingkungan. Hal lainnya yaitu konsumen Bionic Farm tidak menjadikan pengetahuan terhadap lingkungan untuk keputusan pembelian produk organik.

Sikap tidak signifikan terhadap keputusan pembelian produk, hasil ini berbeda dengan Kim dan Chung (2011) dan Naido dan Ramatsetse (2016). Adapun hal yang membuat hasil penelitian ini berbeda dengan penelitian di atas, yaitu pertama produk Bionic Farm masih terbatas pada distribusinya, hal ini menyebabkan distribusinya terbatas sehingga membentuk sikap yang berbeda. Kedua, penelitian sebelumnya menjelaskan adanya norma subjektif yang memengaruhi konsumen untuk membentuk sikap sedangkan hasil penelitian ini 
adanya kekuatan eksternal konsumen dalam keputusan pembelian. Hal ini dapat terlihat bahwa adanya keputusan pembelian berdasarkan green marketing. Ketiga, penelitian sebelumnya menjelaskan bahwa nilai korelasi antara sikap dan keputusan kecil namun siginifikan. Hal yang berpengaruh dan memiliki korelasi besar yaitu adanya persepsi kesehatan dan lingkungan dalam keputusan pembelian produk organik.

\section{Pengaruh Total dan Pengaruh Tidak Langsung}

Tabel 1 menunjukkan bahwa pengaruh total dari variabel green marketing (X1), kesadaran lingkungan (X2) dan kesadaran kesehatan (X3). Pengaruh total menunjukkan adanya pengaruh langsung dan tidak langsung dari variabel laten eksogen terhadap variabel laten endogen. Berdasarkan hasil diperoleh bahwa variabel green marketing tidak terdapat pengaruh tidak langsung green marketing terhadap keputusan pembelian melalui sikap sebagai variabel intervening. Hal ini disebabkan variabel sikap tidak signifikan terhadap keputusan pembelian sehingga pengaruh tidak langsung juga tidak signifikan. Oleh karena itu, jika green marketing semakin meningkat maka keputusan pembelian produk pangan organik di Bionic Farm juga akan semakin meningkat secara langsung tanpa harus adanya pengaruh tidak langsung dari sikap konsumen tersebut.

Kesadaran lingkungan tidak berpengaruh terhadap keputusan pembelian melalui sikap. Kesadaran lingkungan tidak dapat dijadikan acuan baik secara langsung maupun melalui sikap untuk keputusan pembelian. Ini menunjukkan bahwa mereka mengetahui dalam memutuskan membeli sesuatu mereka tetap harus sadar bahwa lingkungan memang perlu diperhatikan dan dijaga tanpa harus menunjukkan sikap mereka akan hal tersebut. Karena setiap produk dan jasa yang mereka gunakan itu banyak bersumber dari alam maka sebagai timbal baliknya mereka juga akan tetap memprioritaskan untuk menjaga lingkungan dengan baik tanpa perlu menunjukkan sikap mereka.

Berdasarkan hasil penelitian kesadaran kesehatan tidak signifikan melalui sikap terhadap keputusan pembelian produk organik Bionic Farm. Hal ini menunjukkan bahwa setiap orang dalam memutuskan untuk menggunakan suatu barang atau jasa pasti menyadari untuk mencantumkan perihal kesehatan di dalamnya. Kesehatan yang nilai mahal ini membuat mereka harus teliti dan objektif dalam menentukan menggunakan suatu produk tanpa harus menunjukan sikap mereka akan hal tersebut. Mereka akan memutuskan untuk membeli atau menggunakan produk ini bukan karena melihat dari sikap mereka terhadap produk itu namun karena sadar akan kebutuhan kesehatan itu penting bagi mereka. Ini sesuai dengan nilai jalur koefisien kesadaran kesehatan lebih besar pengaruh langsung dibandingkan pengaruh tidak langsung melalui sikap.

\section{Implikasi Manajerial}

Implikasi yang dapat diberikan yaitu membuktikan bahwa produk Bionic Farm aman dikonsumsi dan terbukti alami melalui sertifikasi-sertifikasi terkait seperti sertifikasi ISO 22000 tentang keamanan pangan, sudah terakreditasi oleh lembaga organik nasional sehingga dapat menjadi acuan konsumen bahwa produk organik dari Bionic Farm benar-benar aman, dan alami. Bionic Farm juga dapat memanfaatkan media sosial sebagai media promosi atau juga melalui event-event produk organik, pecinta lingkungan, dan melakukan sponsor untuk produk ramah lingkungan untuk memperkenalkan produk yang diproduksi. Hal lainnya yang dapat direkomendasikan kepada Bionic Farm yaitu menggunakan packaging yang ramah lingkungan dengan memanfaatkan produk-produk yang bisa didaur ulang, seperti menggunakan bungkusan kertas sebagai pengganti plastik. Menjamin kepada konsumen oleh Bionic Farm yaitu dengan mencantumkan kandungan gizi yang akan diperoleh dari setiap produk yang mereka produksi baik itu produk olahan maupun yang tidak diolah. Serta menjamin kebersihan dan keamanan dari produk dengan mencantumkan sertifikat yang didapatkan oleh perusahaan pada setiap kemasan produk.

\section{KESIMPULAN DAN SARAN}

\section{Kesimpulan}

Hasil uji model SEM menunjukkan bahwa green marketing dan kesadaran lingkungan signifikan terhadap sikap. Sedangkan, kesadaran kesehatan tidak signifikan terhadap sikap. Selanjutnya, Hasil uji SEM menunjukkan bahwa green marketing dan kesehatan berpengaruh terhadap keputusan pembelian produk organik. Sedangkan, kesadaran lingkungan dan sikap tidak signifikan terhadap keputusan pembelian. 


\section{Saran}

Hasil penelitian ini dapat dijadikan pertimbangan bagi PT Bionic Farm untuk strategi selanjutnya. Adapun beberapa saran yang diajukan berdasarkan implikasi manajerial yang sudah dijelaskan pada subbab sebelumnya. Adapun saran untuk penelitian selanjutnya yaitu menganalisis loyalitas konsumen produk organik dan analisis pengaruh kondisional seperti wabah penyakit atau bencana alam terhadap pembelian produk organik.

\section{DAFTAR PUSTAKA}

[AMA] American Marketing Association (USA). 2009. Green marketing. https://www.ama.org/.[22 Juni 2017]

Asif M, Xuhui W, Nasiri A, Ayyub S. 2018. Determinant factors influencing organic food purchase intention and the moderating role of awareness: A comparative analysis. Food Quality and Preference 63(8):144-150. https:// doi.org/10.1016/j.foodqual.2017.08.006

Balawera A. 2013. Green marketing dan corporate social responsibility pengaruhnya terhadap keputusan pembelian konsumen melalui minat membeli produk organik di freshmart kota Manado. EMBA 1(4):2117-2129.

Beltran LS, Blanco JEE, Morales LFB. 2015. Marketing mix influencing organic foods purchase of Mexican consumers. Proceedings of the 13th International Conference.

Chekima B, Oswald AI, Wafa SAWSK, Chekima K. 2017. Narrowing the gap: Factors driving organic food consumption. Journal of Cleaner Production 166(8):1438-1447. https://doi. org/10.1016/j.jclepro.2017.08.086

Chen MF. 2009. Attitude toward organic foods among Taiwanese as related to health consciousness, environmental attitudes, and the mediating effects of a healthy lifestyle. British Food Journal 111(2):165-178. https://doi. org/10.1108/00070700910931986

Ghozali I, Latan. 2014. Structural Equation Modeling, Metode Alternatif dengan Partial Least Square (PLS) dilengkapi software Smartpls 3.0 Xlstat 2014 dan WarpPLS 4.0. Ed ke-4. Semarang: Universitas Diponegoro Semarang.

[IFOAM] International Federation of Organic Agriculture Movements. 2018. Persyaratan
Produk Pangan Organik. Jakarta: IFOAM.

Hair JF, Ringle CM, Sarstedt M. 2006. PLS-SEM: indeed a silver bulllet. Journal of Marketing Theory and Practice 19(2):139-151. https://doi. org/10.2753/MTP1069-6679190202

Hansen T, Sørensen MI, Eriksen MLR. 2018. How the interplay between consumer motivations and values influences organic food identity and behavior. Food Policy 74(1):39-52. https://doi. org/10.1016/j.foodpol.2017.11.003

Kim HY, Chung JE. 2011. Consumer purchase intention for organic personal care products. Journal of Consumer Marketing 28(1):40-47. https://doi. org/10.1108/07363761111101930

Kotler P. 2002. Manajemen Pemasaran. Jakarta: Prenhallindo.

Kotler P, Keller. 2009. Manajemen pemasaran. Ed. ke13. Jakarta: Erlangga.

Naido V, Ramatsetse MH. 2016. Assessment of the consumer purchase intentions of organic food at the Hazel food market in Pretoria, South Africa. Environmental Economics 7(3):81-88. https:// doi.org/10.21511/ee.07(3).2016.10

Neoloka A. 2008. Kesadaran Lingkungan. Jakarta: PT Rin-eka Cipta.

Rahmalia W, Hakim DB, Budidarmo RR. 2016. Sikap terhadap marketing mix dan proses pengambilan keputusan pembelian konsumen pada Daebak Fan Cafe, Depok. Jurnal Aplikasi Bisnis dan Manajemen 2(3):230-238. https://doi. org/10.17358/JABM.2.3.230

Risyamuka IK, Mandala K. 2015. Pengaruh green marketing terhadap keputusan pembelian produk hijau di restoran sari organik ubud. E-Jurnal Manajemen 4(2): 524-543.

Savale TK, Sharma AF, Patil PU. 2012. Green Marketing: Opportunities and Challenges. IJCA Proceedings on International Conference in Computational Intelligence. New York: Foundation of Computer Science.

Schiffman L, Kanuk L. 2010. Counsumer Behavior. London: Pearson.

Shaharudin MR, Pani JJ, Mansor SW, Elias SJ. 2010. Purchase intention of organic food; perceived value overview. Canadian Social Science 6(1):70-79. https://doi.org/10.5539/ijms. v2n1p96

Soerjanatamihardja KA, Fachira I. 2017. Study of perception and attitude towards green marketing of Indonesian cosmetics consumers. Journal of Business and Management 6(1):160-172. 
Suprapti W. 2010. Perilaku Konsumen Pemahaman Dasar dan Aplikasinya dalam Strategi Pemasaran. Bali: Udayana University Press.

Syahrivar J, Rizky M. 2017. Factors influencing environmental friendly product consumption consciousness in Karawang. Kompetensi-Jurnal Manajemen Bisnis 12(1):49-60.

Wibowo SF. 2011. Karakteristik konsumen berwawasan lingkungan dan hubungannya dengan keputusan membeli produk ramah lingkungan. Econo
Sains 9(2):192-202. https://doi.org/10.21009/ econosains.0092.09

Wijayanto SH. 2008. Structural Equation Modelling dengan LISREL 8.8. Yogyakarta: Graha Ilmu.

Yazdanifard R, Mercy IE. 2011. The impact of green marketing on customer satisfaction and environmental safety. International Conference on Computer Communication and Management 5(1):637-641. 